\title{
Function and Heterogeneity of Human Fc Receptors for Immunoglobulin G
}

\author{
Jay C. Unkeless \\ Department of Biochemistry, Mount Sinai School of Medicine, New York, New York 10029
}

The recognition of foreign antigens by receptors on the surface of cells of the immune system is a fundamental feature of immune defenses. The receptor systems involved include the $\mathrm{T}$ cell receptor complex, surface Ig of B cells, class I and II histocompatibility antigens, CD4, CD8, complement receptors, and receptors for the $\mathrm{Fc}$ domain of $\operatorname{IgG}\left(\mathrm{Fc}_{\gamma} \mathrm{R}\right) .{ }^{1}$ It is noteworthy that, except for the complement receptors, all of these are membrane-bound glycoproteins that are members of the Ig supergene family (see Williams and Barclay [1] for review). Although the existence of $\mathrm{Fc}_{\gamma} \mathrm{R}$ has been appreciated since the late 1960s (2), it was only with the advent of MAb technology that the complexity of the $\mathrm{Fc}_{\gamma} \mathrm{R}$ family has become evident. With the cloning of the genes for several murine and human $\mathrm{Fc}_{\gamma} \mathrm{Rs}$, it is apparent that the notion of a MAb defining one $\mathrm{Fc}_{\gamma} \mathrm{R}$ is simplistic, since several proteins with widely divergent transmembrane and cytoplasmic domains, but conserved extracellular domains, may be recognized by the same MAb reagent. This review will focus on recent progress in the elucidation of the human $\mathrm{Fc}_{\gamma} \mathrm{R}$ family; previous reviews cover the older literature and the murine system in more detail (3-6).

The provisional nomenclature discussed at a meeting on Fc receptors and Ig binding factors sponsored by the Federation of American Societies for Experimental Biology in June, 1987 is based primarily on MAb reactivity and secondarily on subclass specificity, and is summarized in Table $\mathrm{I}$.

\section{Structure of murine $F c_{\gamma} R s$}

The cloning of murine $\mathrm{Fc}_{\gamma} \mathrm{Rs}$ has been accomplished by several groups (7-10). These studies reveal that the murine $\mathrm{Fc}_{\gamma} \mathrm{Rs}$ consist of a mature extracellular domain of $\sim 180$ amino acids, which can be subdivided into two homologous domains most closely related to the Ig constant region $\mathrm{C} 2$ domain set (1). Each subdomain contains two cysteine residues that form disulfide bridges $(11,12)$ with loops from 43 to 45 residues long, in contrast to most other members of the Ig gene superfamily, which have longer loops. Other members of the $\mathrm{C} 2$ set are adhesion molecules such as NCAM, myelin-associated

Address correspondence to Dr. Jay C. Unkeless, Department of Biochemistry, Box 1020, The Mount Sinai Medical Center, One Gustave L. Levy Place, New York, NY 10029-6574.

Received for publication 10 October 1988.

1. Abbreviations used in this paper: $\mathrm{ADCC}$, antibody-dependent cellular cytotoxicity; $\mathrm{FC}_{\gamma} \mathrm{R}$, receptor for the $\mathrm{Fc}$ domain of IgG; PIG, phosphatidylinositol glycan; PIPLC, phosphatidyl inositol-specific phospholipase $\mathrm{C}$; $\mathrm{PNH}$, paroxysmal nocturnal hemoglobinuria.

J. Clin. Invest.

(c) The American Society for Clinical Investigation, Inc. 0021-9738/89/02/0355/07 \$2.00

Volume 83, February 1989, 355-361 protein, $\mathrm{CD} 2$, the $\epsilon$ chain of $\mathrm{CD} 3$, and peptide receptors for PDGF, CSF-1, and IL-6 (13).

There are two genes encoding the low avidity muFc $_{\gamma}$ RII proteins, $\operatorname{muFc}_{\gamma} \mathrm{RII} \alpha$ and $\operatorname{muFc}_{\gamma} \mathrm{RII} \beta$, which share $95 \%$ homology in the extracellular domains but differ in their transmembrane and cytoplasmic domains. The muFc ${ }_{\gamma}$ RII $\alpha$ gene is transcribed in macrophages, and has a transmembrane domain remarkable for a charged aspartyl residue in the bilayer leaflet and a 26-residue basic cytoplasmic domain. The protein sequence of the transmembrane domain of the muFc ${ }_{\gamma} \mathrm{RII} \alpha$ is homologous to the transmembrane domain of the IgE-binding $\alpha$ subunit of the high avidity basophil/mast cell $\mathrm{Fc}_{\boldsymbol{\epsilon}} \mathrm{RI}(14,15)$, which suggests that the two receptors may have a similar mechanism of signal transduction. The $\operatorname{muFc}_{\gamma} \mathrm{RII} \beta$ gene has two transcripts, $\operatorname{muFc}_{\gamma} \mathrm{RII} \beta 1$ and $\mathrm{muFc}_{\gamma} \mathrm{RII} \beta 2$, that differ in a 46-amino-acid insertion in the cytoplasmic domain of the muFc $_{\gamma} \operatorname{RII} \beta 1$ protein. The transmembrane domain of the $\operatorname{muFc}_{\gamma} \mathrm{RII} \beta$ gene has no charged amino acids. The structure of $\mathrm{muFc}_{\gamma} \mathrm{RI}$, the high avidity receptor that binds murine IgG2a and human IgG1, has not yet been determined.

$h u F c_{\gamma} R I$

$\mathrm{HuFc}_{\gamma} \mathrm{RI}$, found predominantly on monocytes and macrophages, binds monomeric human IgG with high avidity $\left(K_{\mathrm{a}}\right.$ $=1-3 \times 10^{8} \mathrm{M}^{-1}$ ) and with a subclass specificity of $\operatorname{IgG} 1$ $>\mathrm{IgG} 3>\mathrm{IgG} 4>\operatorname{IgG} 2$ (16), in addition to binding murine IgG2a with high avidity. One epitope on murine IgG2a and human IgGl that binds to huFc${ }_{\gamma}$ RI has now been localized to the $\mathrm{NH}_{2}$-terminal portion of the $\mathrm{C}_{\mathrm{H}} 2$ domain by Duncan et al. (17). The sequence of murine IgG2a and human IgG1 from residue 234 of the heavy chain is LLGGP. A single amino acid substitution, which converts the homologous sequence of murine IgG2b from LEGGP to LLGGP, increased the binding of the mutant murine IgG2b to huFc $\mathrm{c}_{\gamma} \mathrm{RI} 100$-fold. There may be other epitopes involved in binding of $\mathrm{IgG}$ to $\mathrm{huFc}_{\gamma} \mathrm{RI}$ and the murine counterpart, $\mathrm{muFc}_{\gamma} \mathrm{RI}$, as suggested by inhibition of binding of murine IgG2a immune aggregates to macrophages by aggregated $\mathrm{CNBr}$ fragments from both the $\mathrm{C}_{\mathrm{H}} 2$ and $\mathrm{C}_{\mathrm{H}} 3$ domains of IgG2a (18).

$\mathrm{HuFc}_{\gamma}$ RI was purified by affinity chromatography from monocytes and the U937 monocytic cell line (19). Several MAbs (32.2, FR51, 10.1) (20-22) have been described that immunoprecipitate $\mathrm{huFc}_{\gamma} \mathrm{RI}$, but are apparently directed against epitope(s) not directly associated with the binding site of the receptor since they do not efficiently inhibit binding of IgG. Adsorption of huFc$c_{\gamma} \mathrm{RI}$ from cell lysates containing $\mathrm{huFc}_{\gamma} \mathrm{RI}$ on microtiter wells coated with MAb 32.2 conferred high affinity IgG binding on the wells, confirming the anti$\mathrm{Fc}_{\gamma} \mathrm{RI}$ specificity of MAb 32.2 (23). The protein has an $M_{\mathrm{r}}$ of 72,000 on SDS-PAGE, and is heavily glycosylated. After removal of $\mathrm{N}$-linked carbohydrate of $N$-glycosidase-F a core protein with an $M_{\mathrm{r}}$ of 40,000 was found (21). 
Table I. F $c_{\gamma} R$ Nomenclature

\begin{tabular}{|c|c|c|c|}
\hline $\begin{array}{c}\text { Proposed } \\
\text { nomenclature }\end{array}$ & Previous nomenclature & Cell types bearing receptor & Anti-Fc ${ }_{\gamma} R$ MAbs \\
\hline huFc $\mathbf{\gamma}_{\gamma} \mathbf{R I}$ & $\mathrm{Fc}_{\gamma} \mathbf{R}_{\mathrm{hi}}, \mathrm{Fc}_{\gamma} \mathbf{R}_{\mathrm{p} 72}$ & Monocyte/macrophage, IFN- $\gamma$-stimulated neutrophil & 32.2, FR51, $10.1(20-22)$ \\
\hline huFc $_{\gamma}$ RII & $\mathrm{Fc}_{\gamma} \mathbf{R}_{\mathrm{p} 40}$ & Monocyte/macrophage neutrophil, eosinophil, platelet, B cell & IV.3 (35) \\
\hline $\mathrm{huFc}_{\boldsymbol{\gamma}} \mathrm{RIII}$ & $\mathrm{Fc}_{\gamma} \mathbf{R}_{\mathrm{lo}}, \mathrm{Fc}_{\gamma} \mathrm{R}_{\mathrm{p} 50-70}$ & NK cells, neutrophils, eosinophils, macrophages, not on monocytes & $3 G 8$, B73.1, leu $11 a, b, c(34,53,59)$ \\
\hline
\end{tabular}

The huFc $\mathrm{c}_{\gamma} \mathrm{RI}$ is thought to play a role in antibody-dependent cellular cytotoxicity (ADCC) reactions. Graziano and Fanger (24) have demonstrated killing by monocytes of myelomas bearing both anti-huFc $\mathrm{c}_{\gamma} \mathrm{RI}$ and anti-huFc${ }_{\gamma} \mathrm{RII}$ MAb. IFN- $\gamma$, which in many systems acts to potentiate ADCC reactions and to enhance the oxidative burst (25), increases the expression of $\mathrm{HuFc}_{\gamma} \mathrm{RI}$ 8-10-fold (26). IFN- $\gamma$ treatment of U937 cells potentiates ADCC mediated by murine IgG2a (27), the subclass of mouse IgG that binds most avidly to $\mathrm{huFc}_{\gamma} \mathrm{RI}$. In addition, IFN- $\gamma$ induces expression of huFc ${ }_{\gamma} \mathrm{RI}$ on neutrophils, which usually do not express this receptor (28-30). The IFN- $\gamma$-treated neutrophils have increased ADCC potential and mediate $A D C C$ via the induced $h^{2} \mathrm{Fc}_{\gamma} \mathrm{RI}$ (29). Other agents, such as glucocorticoids and retinoic acid $(30,31)$, and the C5a split product of complement (32), have also been reported to induce huFc ${ }_{\gamma} \mathrm{RI}$ expression.

Of interest is a report by Ceuppens et al. (33) of a Dutch family, four members of which have monocytes that lack $\mathrm{huFc}_{\gamma} \mathrm{RI}$ binding sites. Although the monocytes from these individuals do not bind IgG with high avidity, they show no increased susceptibility to infection. This suggests that the $\mathrm{Fc}_{\gamma} \mathrm{R} /$ complement receptor systems have enough degeneracy in terms of function that absence of the huFc ${ }_{\gamma} \mathrm{RI}$ molecule from the monocyte/macrophage lineage does not seriously compromise immune defenses.

\section{$h u F c_{\gamma} R I I$}

$\mathrm{HuFc}_{\gamma} \mathrm{RII}, \mathrm{CDw} 32$ (34), is distributed on a wide variety of cells, including monocytes, platelets, neutrophils, B cells, and the $\mathrm{K} 562$ cell line. The protein was first isolated by affinity chromatography on IgG Sepharose (19), and subsequently an MAb, IV.3, was isolated that immunoprecipitates a protein of $M_{\mathrm{r}} 40,000$ (35). MAb IV.3 blocks IgG-mediated aggregation of platelets, which bear only huFc $\gamma_{\gamma} \mathrm{RII}$. HuFc $\mathrm{HIII}_{\gamma}$ is a low avidity receptor first identified on U937 cells by the binding of aggregated murine IgG2b at low ionic strength (36). The receptor binds human IgG1 with $K_{\mathrm{a}}=\sim 2 \times 10^{6} \mathrm{M}^{-1}$. The order of binding activity to recombinant huFc ${ }_{\gamma} \mathrm{RII}$ expressed in COS cells is IgG1 > IgG2 = IgG4 $\gg \operatorname{IgG} 3$ (37).

$\mathrm{HuFc}_{\gamma} \mathrm{RII}$ apparently plays only a minor role in the binding of IgG-sensitized erythrocytes to neutrophils, monocytes, or macrophages since MAb IV.3, which inhibits huFc $\mathrm{CIII}_{\gamma}$, has only a slight effect on binding of immune aggregates $(38,39)$. $\mathrm{HuFc}_{\gamma} \mathrm{RII}$ will direct ADCC by monocytes and the cytotoxic potential of this receptor is increased in neutrophils by treatment with IFN- $\gamma$, although the density of $\operatorname{huFc}_{\gamma} \mathrm{RII}$ is not elevated by IFN- $\gamma(24)$. HuFc ${ }_{\gamma}$ RII may play a vital role in triggering the oxidative burst, since this response to aggregated IgG is blocked by MAb IV.3 or its $F\left(a^{\prime}\right)_{2}$ fragment (20). Willis et al. (40) also demonstrate, with a different anti-huFc ${ }_{\gamma}$ RII $\mathrm{MAb}$, that triggering of the oxidative burst and release of lyso- somal enzymes from neutrophils is dependent on crosslinking of the receptors. Neutrophils that have only huFc $\mathrm{c}_{\gamma} \mathrm{RII}$ on their membrane can be isolated from patients with paroxysmal nocturnal hemoglobinuria (PNH). Yet these neutrophils can mediate a normal oxidative burst in response to stimulation with IgG-coated latex (41), confirming the role of huFc ${ }_{\gamma}$ RII in triggering oxidative metabolism by neutrophils. Similar results are obtained with neutrophils that have been digested with elastase, which removes most of huFc $\mathrm{C}_{\gamma}$ RIII but leaves the $\mathrm{huFc}_{\gamma} \mathrm{RII}$ molecule intact. Elastase-treated neutrophils release superoxide in response to aggregated IgG, and the superoxide release is inhibited by preincubation with MAb IV.3 (42).

The monocyte-dependent $T$ cell response to IgG1 antiCD3 MAbs is blocked by anti-huFc $\mathrm{C}_{\gamma}$ RII MAb IV.3 (43) which demonstrates the role of huFc${ }_{\gamma} \mathrm{RII}$ in crosslinking the antiCD3 MAb on the T cell plasma membrane. Furthermore, cloned huFc ${ }_{\gamma}$ RII expressed in mouse $\mathrm{L}$ cells will mediate an anti-CD3 dependent $T$ cell response (44). There is allotypic variation in $\mathrm{huFc}_{\gamma} \mathrm{RII}$, which has two alleles identified by an isoelectric point polymorphism (45). The polymorphism is reflected in different accessory cell-dependent mitogenic responses of T cells to murine IgG1 anti-CD3 MAbs. However, the $T$ cells of $\sim 30 \%$ of normal individuals do not proliferate in the presence of monocytes and murine IgG1 anti-CD3 antibody, due to the failure to crosslink the T cell $\mathrm{CD} 3$ via the monocyte huFc ${ }_{\gamma}$ RII. The IgG1 anti-CD3 MAbs can trigger T cell mitogenesis in nonresponding individuals when the MAb is coupled to Sepharose (46-48). The percentage of individuals nonresponsive to IgG1 anti-CD3 MAbs correlates well with the isoelectric polymorphism of huFc ${ }_{\gamma} \mathrm{RII}$ (45). The individuals who fail to respond to IgG1 anti-CD3 MAbs apparently fail to do so because the homozygous nonresponder allele of huFc $\mathrm{C}_{\gamma} \mathrm{RII}$ does not bind murine IgG1 (49). There are also reproducible differences in the amount of huFc $\mathrm{F}_{\gamma} \mathrm{RII}$ detected on platelets from different individuals. Platelets with higher levels of huFc ${ }_{\gamma} \mathrm{RII}$ are more sensitive to aggregation by IgG complexes (50).

The huFc ${ }_{\gamma}$ RII cDNA has been cloned $(37,51,52)$. The leader sequence of huFc ${ }_{\gamma}$ RII shares homology with the $\operatorname{muFc}_{\gamma} \mathrm{RII} \alpha$ transcript, but the transmembrane domain of huFc $\gamma_{\gamma}$ RII bears homology to $\mathrm{muFc}_{\gamma}$ RII $\beta$. The cytoplasmic domain, which is 76 amino acids long, is composed of neutral and hydrophobic residues and bears no homology to either murine $\mathrm{Fc}_{\gamma} \mathrm{R}$. Two mRNA transcripts, of 1.6 and $2.5 \mathrm{~kb}$, are present in lines that express huFc ${ }_{\gamma}$ RIII. The different transcripts may reflect use of different polyadenylation signals.

There may be other huFc ${ }_{\gamma}$ RII genes yet to be characterized. Daudi, an EBV-transformed B cell line, expresses a low affinity $\mathrm{Fc}_{\gamma} \mathrm{R}$ of $40,000 M_{\mathrm{r}}$, and synthesizes transcripts that hybridize with huFc ${ }_{\gamma}$ RII probes. However, the anti-huFc $\mathrm{F}_{\gamma} \mathrm{RII} \mathrm{MAb}$ IV.3 does not bind to Daudi, although it does immunopre- 
cipitate the two different allotypes of huFc $\mathrm{FII}_{\gamma}$. Furthermore, Stuart et al. (51) isolated MAbs directed against peptides immediately $\mathrm{COOH}$-terminal to the first cysteine in each disulfide pair in the Ig-like domains of the predicted $\mathrm{huFc}_{\gamma} \mathrm{RII}$ sequence. Although these sera did bind to U937 and huFc $\mathrm{C}_{\gamma} \mathrm{RII}$ transfectants, they did not react with Daudi. Thus it would appear that Daudi has a huFc $\mathrm{RII}_{\gamma}$ that differs from that cloned so far.

\section{$h u F c_{\gamma} R I I I$}

$\mathrm{HuFc}_{\gamma} \mathrm{RIII}, \mathrm{CD} 16$, is expressed on neutrophils, NK cells, a minor population of $\mathrm{T}$ cells, eosinophils, and on tissue macrophages but not on monocytes (38, 53-55). In the granulocyte lineage; huFc ${ }_{\gamma} \mathrm{RIII}$ is expressed at the metamyelocyte stage. The HL-60 promyelocytic cell line, which does not express huFc ${ }_{\gamma}$ RIII, can be induced to do so by DMSO or retinoic acid, which induces a more mature granulocytic morphology. The recent cloning and expression of huFc $\mathrm{CIII}_{\gamma}$ in COS cells has facilitated a study of receptor specificity. $\mathrm{HuFc}_{\gamma} \mathrm{RIII}$ binds human IgG1 and IgG3 with a $K_{\mathrm{a}} \sim 5 \times 10^{5} \mathrm{M}^{-1}$ and does not bind human IgG2 and IgG4 (56). These results agree with previous results obtained by Spiegelberg et al. (57) and Gergely et al. (58).

Several lines of evidence suggest that there may be a family of huFc $\mathrm{F}_{\gamma} \mathrm{RIII}$ molecules that have highly conserved extracellular domains but may differ in other domains. There are immunological differences between neutrophil and NK cell antigens that can be demonstrated with anti- $\mathrm{Fc}_{\gamma}$ RIII MAbs, and the $\mathrm{NA} / \mathrm{NA} 2$ alloantigen system of huFc $\mathrm{CIII}_{\gamma}$ is apparently restricted to neutrophils (59). Analysis of SDS-PAGE of huFc ${ }_{\gamma}$ RIII immunoprecipitated from macrophages, neutrophils, and NK cells before and after deglycosylation also illustrates differences between these receptors. Isolation of huFc ${ }_{\gamma}$ RIII from monocytes cultured in vitro for $14 \mathrm{~d}$ revealed a protein of $M_{\mathrm{r}} 55,000$, which was not altered by digestion with $N$-glycanase (39). The neutrophil receptor, by contrast, exhibited a broad band on SDS-PAGE from 50,000-70,000 $M_{\mathrm{r}}$, which is reduced to a doublet of $28,000-29,000 M_{\mathrm{r}}$ after deglycosylation. The huFc $\mathrm{HIII}_{\gamma}$ molecule on NK cells is also different from the neutrophil receptor, since deglycosylation leads to a complex pattern with peptides of $36,000,40,000$, and $44,000 M_{\mathrm{r}}(60)$.

The neutrophil huFc $\mathrm{F}_{\gamma} \mathrm{RIII}$ molecule has now been identified as a membrane protein that has a phosphatidylinositol glycan (PIG) membrane anchor $(61,62)$. The neutrophil $\mathrm{huFc}_{\gamma} \mathrm{RIII}$ is released from the cells upon treatment with phosphatidyl inositol-specific phospholipase C (PIPLC). Furthermore, neutrophils from patients with $\mathrm{PNH}$, an acquired clonal stem cell disorder characterized by a defect in the biosynthesis of the PIG anchor, show a marked deficiency in huFc $_{\gamma}$ RIII expression. Decay accelerating factor and acetylcholinesterase, two other PIG-anchored proteins, are also deficient in the membranes of patients with PNH. Both the NA1 and NA2 alloantigens of huFc $\mathrm{h}_{\gamma} \mathrm{RIII}$ are released by PIPLC. Results of expression in COS cells on a cDNA encoding huFc $\mathrm{c}_{\gamma}$ RIII confirm the presence of a PIG anchor (56).

The functional significance of the PIG anchor on neutrophils remains to be determined. Huizinga et al. (62) report that huFc $_{\gamma} \mathrm{RIII}$ is released upon stimulation of PMN by FMLP, a chemotactic peptide. This is consistent with a previous report (63) demonstrating a loss of $\mathrm{Fc}_{\gamma} \mathrm{R}$ expression on neutrophils after stimulation with phorbol esters because both FMLP and immune complexes activate protein kinase $\mathrm{C}$.

There is, however, some question as to whether the $\mathrm{huFc}_{\gamma} \mathrm{RIII}$ molecule on all cell types has a PIG membrane anchor. Thus far, all the members of the Fc receptor family that have been cloned have had two Ig-like extracellular domains, each of $\sim 85$ amino acids. The size of the deglycosylated huFc $\mathrm{C}_{\gamma}$ RIII molecules isolated from NK cells (60) and macrophages (39) is greater than the 26,000-29,000 $M_{\mathrm{r}}$ deglycosylated $\mathrm{Fc}_{\gamma} \mathrm{RIII}$ molecule reported for neutrophils. Furthermore, while PNH patients have dramatically reduced amounts of huFc ${ }_{\gamma}$ RIII on the neutrophil plasma membrane, the amount of $\mathrm{HuFc}_{\gamma} \mathrm{RIII}$ on cultured monocytes is normal (62). Thus, it is likely that there are other members of the CD16/ $\mathrm{huFc}_{\gamma} \mathrm{RIII}$ family with different transmembrane and/or cytoplasmic domains.

The activation of $\mathrm{NK} \mathrm{huFc}{ }_{\gamma} \mathrm{RIII}$ results in the expression of IL-2 receptor, the transferrin receptor, and the hormones IFN- $\gamma$ and TNF (64). IL-2 and huFc ${ }_{\gamma}$ RIII ligands act synergistically to activate NK cells. Thus the synthesis of TNF, barely stimulated by $100 \mathrm{U} / \mathrm{ml}$ of IL-2, and only stimulated eightfold by Sepharose B73.1 (an anti-huFc $\gamma_{\gamma}$ RIII MAb), is stimulated 50 -fold by a combination of combined IL-2 and Sepharose B73.1. Egawa et al. (65) report that anti-huFc ${ }_{\gamma}$ RIII MAb treatment enhances NK cell activity, and similar results are reported by van de Griend et al. (66). These results have important implications for the mechanism of NK cytotoxicity.

$\mathrm{HuFc}_{\gamma} \mathrm{RIII}$ is present in high concentration on Kuppfer cells in the liver and on macrophages in the red pulp of the spleen, both loci involved in clearance of immune complexes. Blockade of the mononuclear phagocyte system of chimpanzees with either the anti-Fc $\mathrm{c}_{\gamma} \mathrm{RIII}$ MAb $3 \mathrm{G} 8$ or its Fab fragment resulted in a dramatic blockade of in vivo clearance of autologous erythrocytes coated with antibody directed against a minor blood group antigen (67). These results suggest that, at least for this type of large immune complex, huFc $\mathrm{RIII}_{\gamma}$ on macrophages may be the major receptor involved in clearance. Blockade of huFc ${ }_{\gamma}$ RIII by MAb 3G8 was tested as a therapeutic treatment of chronic immune thrombocytopenic purpura, a disease characterized by anti-platelet antibody (68). Infusion of 3G8 in one reported case had a dramatic short-term effect on platelet levels which rose to normal levels and subsided after $2 \mathrm{wk}$. Reinfusion of the MAb resulted in a blunted response, possibly due to production of antibodies against the murine IgG.

The huFc $\mathrm{c}_{\gamma} \mathrm{RIII}$ cloned by Simmons and Seed (56) using a eukaryotic expression shuttle vector from a cDNA library constructed from human placenta reveals greatest homology with the $\mathrm{muFc}_{\gamma} \mathrm{RII} \alpha$ gene. The predicted protein has a short transmembrane domain followed by only four residues, only one of which is basically charged. The recombinant huFc $\mathrm{C}_{\gamma} \mathrm{RIII}$ expressed in COS cells is immunoreactive with a panel of anti-huFc ${ }_{\gamma}$ RIII MAbs, has an $M_{\mathrm{r}}$ of 50,000-70,000, is reduced in size to $26,000 M_{\mathrm{r}}$ after $N$-glycanase digestion, and is released from the membrane of transfected cells by digestion with PIPLC, all characteristics of the neutrophil huFc ${ }_{\gamma}$ RIII. There is a conflict, however, between the results of Simmons and Seed (56), who state that the receptor they have isolated is that of NK cells, and Lanier et al. (60) since the latter group reports the NK huFc ${ }_{\gamma}$ RIII has a deglycosylated size of $36-44 \mathrm{kD}$, 
clearly different from the 26-29 kD deglycosylated neutrophil $\operatorname{huFc}_{\gamma}$ RIII $(39,60)$.

\section{Mechanism of signal transduction}

As discussed previously, the neutrophil receptor responsible for triggering the oxidative burst is huFc $\mathrm{f}_{\gamma} \mathrm{RII}$. This receptor may be linked to protein kinase $C$ via inhibitory $G$ proteins, since Feister et al. (69) found that pertussis toxin inhibited the oxidative burst of neutrophils triggered by both the chemotactic peptide FMLP and by cross-linking huFc ${ }_{\gamma}$ RIII via MAb $\mathrm{KuFc79}$. Degranulation triggered by the MAb cross-linking was only partially inhibited by pertussis toxin, in contrast to the total inhibition of degranulation observed under the same conditions for FMLP stimulation. Gresham et al. (70) also find that the phagocytic response of neutrophils mediated by $\mathrm{Fc}_{\gamma} \mathrm{R}$ is partially linked through $G$ protein. Phagocytosis of EIgG by neutrophils can be stimulated by amphotericin B, by a cytokine from lymphocytes co-cultured with monocytes ingesting EIgG (71), or by phorbol dibutyrate. The stimulation by amphotericin B or cytokine is abrogated by cholera toxin or pertussis toxin, but phorbol dibutyrate stimulation is unaffected by these agents, presumably because the phorbol ester bypasses the steps involving the $\mathrm{G}$ proteins.

The respiratory burst of macrophages is activated by phagocytosis of EIgG, but not by EIgMC. Taking advantage of this, Brozna et al. (72) looked for differential phosphorylation of macrophage proteins from cells ingesting EIgG compared with EIgMC, and found a series of proteins more intensely labeled after EIgG stimulation. Some of these proteins also are phosphorylated after phorbol myristate acetate (PMA) stimulation. The activity of protein kinase $\mathrm{C}$ in particulate fractions also was dramatically increased within minutes of stimulation by $\mathrm{EIgG}$, consistent with protein kinase $\mathrm{C}$ activation.

The role of $\mathrm{Ca}^{2+}$ in $\mathrm{Fc}_{\gamma} \mathrm{R}$ signalling may differ for different cells and systems. Crosslinking of $\mathrm{Fc}_{\gamma} \mathrm{R}$ of macrophages (73) and neutrophils (74) has been reported to trigger $\mathrm{Ca}^{2+}$ mobilization. This may, however, be a secondary phenomenon, since phagocytosis of EIgG is not inhibited after the free $\mathrm{Ca}^{2+}$ is buffered to 1-10 nm by EGTA or Quin2 (75).

Phillips and Parker $(76,77)$ have shown that ternary crosslinking of membrane $\mathrm{Ig}$ and $\mathrm{Fc}_{\gamma} \mathrm{R}$ of murine $\mathrm{B}$ lymphocytes inhibits stimulation otherwise found with anti- $\mu$ or anti- $\delta$ $\mathrm{F}\left(\mathrm{ab}^{\prime}\right)_{2}$. Murine B cells stimulated by anti- $\mu$ Ig or anti- $\delta \mathrm{F}\left(\mathrm{ab}^{\prime}\right)_{2}$ show a transient $\mathrm{Ca}^{2+}$ response and generation of inositol triphosphate, and are stimulated to enlarge and express surface Ia. These responses are largely abrogated by intact rabbit anti- $\mu$ or anti- $\delta$, but if the $\mathrm{Fc}_{\gamma} \mathrm{R}$ is blocked by anti-Fc $\mathrm{F}$ MAb $2.4 \mathrm{G} 2$, the responses are restored (78). Goroff and Finkelman (79) report that the stimulatory effect on B cell Ia expression of an IgG2b anti- $\delta$ MAb was not inhibited by the anti-Fc $\mathrm{R}_{\gamma} \mathrm{MAb}$ $2.4 \mathrm{G} 2$, but the stimulation by the univalent $\mathrm{Fab} / \mathrm{Fc}$ anti- $\delta$ MAb was blocked. $\mathrm{Ca}^{2+}$ flux may play a role in activation of NK cells mediated by cross-linking of $\mathrm{CD} 2$ and huFc ${ }_{\gamma}$ RIII (80).

It seems only reasonable that proteins other than the $\mathrm{Fc}_{\gamma} \mathrm{R}$ itself are involved in such complicated cellular behaviors as phagocytosis and ADCC. Monocytes sorted to enrich the Leu $\mathrm{M3}^{+}$population phagocytose EIgG avidly and lyse EIgG only poorly; the reverse is true of the Leu $\mathrm{M3}^{-}$population (81). Similar results were observed with different sublines of the U937 cell line after stimulation with PMA. Sublines that ex- press Leu M3 after PMA treatment phagocytose well but lyse EIgG poorly, and vice versa. In each case the receptors (huFc $c_{\gamma} R I$ and $\mathrm{Fc}_{\gamma} \mathrm{RII}$ ) are presumably the same, yet the final cellular response is different.

\section{Clinical potential of anti-F $c_{\gamma} R M A b s$}

A potentially exciting use for anti-Fc $\mathrm{q}_{\gamma} \mathrm{R}$ MAbs is to direct the cytotoxic potential of $\mathrm{Fc}_{\gamma} \mathrm{R}$-bearing cells to immunologically defined targets. Two potential problems in the use of antitumor antibodies to target ADCC are interference by the high concentrations of IgG found in serum and the capping of antigens triggered by bivalent antibodies. Both difficulties might be bypassed by covalent heteroconjugates between antihuFc $_{\gamma} \mathbf{R}$ MAbs and anti-tumor antibodies. The feasibility of such an approach is shown by experiments in which heteroconjugates were formed between the anti-Fc $\mathrm{F}_{\gamma} \mathrm{RI}$ MAb 32.2 and anti-chicken erythrocyte antibody. These conjugates would direct both monocyte ADCC (82) and ADCC by neutrophils after stimulation with IFN- $\gamma$ (30), which induces huFc ${ }_{\gamma}$ RI. The observed ADCC was not inhibited by $\mathrm{mg} / \mathrm{ml}$ concentration of huIgG, in contrast to monocyte ADCC mediated by anti-target antibody, because MAb 32.2 is not directed against an epitope close to the binding of huFc $\mathrm{F}_{\gamma} \mathrm{RI}$.

A similar approach was used to target NK/K cell ADCC

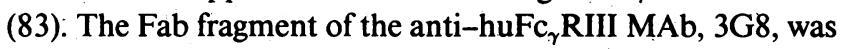
coupled to the Fab fragment of an MAb directed against tumor antigens or DNP groups. The conjugates would direct $\mathrm{NK} / \mathrm{K}$ cell ADCC against cells bearing the appropriate antigen in vitro. The heteroconjugate-directed ADCC was not readily inhibited by cross-linked antibody, and in vivo would neutralize tumor cells in a Winn assay. Activation of the effector cells by IL-2 increased the efficiency of the antineoplastic activity.

\section{Acknowledgments}

I would like to thank Dr. Victoria Freedman and Dr. Eileen Scigliano for editorial assistance.

This work was supported by National Institutes of Health grants $\mathrm{AI}-24322$ and AI-24671.

\section{References}

1. Williams, A. F., and A. N. Barclay. 1988. The immunoglobulin superfamily-domains for cell surface recognition. Annu. Rev. Immunol. 6:381-405.

2. Berken, A., and B. Benacerraf. 1966. Properties of antibodies cytophilic for macrophages. J. Exp. Med. 123:119-144.

3. Dickler, H. B. 1976. Lymphocyte receptors for immunoglobulin. Adv. Immunol. 24:167-214.

4. Unkeless, J. C., H. Fleit, and I. S. Mellman. 1981. Structural aspects and heterogeneity of immunoglobulin Fc receptors. $A d v . I m-$ munol. 31:247-270.

5. Anderson, C. L., and R. J. Looney. 1986. Human leukocyte Ig Fc receptors. Immunol. Today. 7:264-266.

6. Unkeless, J. C., E. Scigliano, and V. H. Freedman. 1988. Structure and function of human and murine receptors for IgG. Annu. Rev. Immunol. 6:251-281.

7. Ravetch, J. V., A. D. Luster, R. Weinshank, J. Kochan, A. Pavlovec, D. A. Portnoy, J. Hulmes, Y. C. Pan, and J. C. Unkeless. 1986. Structural heterogeneity and functional domains of murine immunoglobulin G Fc receptors. Science (Wash. DC). 234:718-725.

8. Hibbs, M. L., I. D. Walker, L. Kirszbaum, G. A. Pietersz, N. J. Deacon, G. W. Chambers, I. F. McKenzie, and P. M. Hogarth. 1986. The murine Fc receptor for immunoglobulin: purification, partial 
amino acid sequence, and isolation of cDNA clones. Proc. Natl. Acad. Sci. USA. 83:6980-6984.

9. Hogarth, P. M., M. L. Hibbs, L. Bonadonna, B. M. Scott, E. Witort, G. A. Pietersz, and I. F. McKenzie. 1987. The mouse Fc receptor for IgG (Ly-17): molecular cloning and specificity. Immunogenetics. 26:161-168.

10. Lewis, V. A., T. Koch, H. Plutner, and I. Mellman. 1986. A complementary DNA clone for a macrophage-lymphocyte Fc receptor. Nature (Lond.). 324:372-375.

11. Hibbs, M. L., B. J. Classon, I. D. Walker, I. F. McKenzie, and P. M. Hogarth. 1988. The structure of the murine Fc receptor for IgG: assignment of intrachain disulfide bonds, identification of N-linked glycosylation sites, and evidence for a fourth form of Fc receptor. $J$. Immunol. 140:544-550.

12. Qu, Z., J. Odin, J. D. Glass, and J. C. Unkeless. 1988. Expression and characterization of a truncated murine $\mathrm{Fc}_{\delta}$ receptor. J. Exp. Med. 167:1195-1210.

13. Yamasaki, K., T. Taga, Y. Hirata, H. Yawata, Y. Kawanishi, B. Seed, T. Taniguchi, T. Hirano, and T. Kishimoto. 1988. Cloning and expression of the human interleukin-6 (BSF-2/IFN $\beta$ 2) receptor. Science (Wash. DC). 241:825-828.

14. Kinet, J. P., H. Metzger, J. Hakimi, and J. Kochan. 1987. A cDNA presumptively coding for the $\alpha$ subunit of the receptor with high affinity for immunoglobulin E. Biochemistry. 26:4605-4610.

15. Shimizu, A., I. Tepler, P. N. Benfey, E. H. Berenstein, R. P. Siragainian, and $P$. Leder. 1988. Human and rat mast cell high affinity immunoglobulin E receptors: characterization of putative $\alpha$-chain products. Proc. Natl. Acad. Sci. USA. 85:1907-1911.

16. Huber, H., S. D. Douglas, J. Nusbacher, S. Kochwa, and R. E. Rosenfield. 1971. IgG subclass specificity of human monocyte receptor sites. Nature (Lond.). 229:419-420.

17. Duncan, A. R., J. M. Woof, L. J. Partridge, D. R. Burton, and G. Winter. 1988. Localization of the binding site for the human highaffinity Fc receptor on IgG. Nature (Lond.). 332:563-564.

18. Diamond, B., L. Boccumini, and B. K. Birshtein. 1985. Site of binding of IgG2b and IgG2a by mouse macrophage Fc receptors by using cyanogen bromide fragments. J. Immunol. 134:1080-1083.

19. Anderson, C. L. 1982. Isolation of the receptor for IgG from a human monocyte cell line (U937) and from human peripheral blood monocytes. J. Exp. Med. 156:1794-1806.

20. Anderson, C. L., P. M. Guyre, J. C. Whitin, D. H. Ryan, R. J. Looney, and M. W. Fanger. 1986. Monoclonal antibodies to Fc receptors for IgG on human mononuclear phagocytes: antibody characterization and induction of superoxide production in a monocyte cell line. J. Biol. Chem. 261:12856-12864.

21. Frey, J., and W. Engelhardt. 1987. Characterization and structural analysis of $\mathrm{Fc} \tau$ receptors of human monocytes, a monoblast cell line (U937) and a myeloblast cell line (HL-60) by a monoclonal antibody. Eur. J. Immunol. 17:583-591.

22. Dougherty, G. J., Y. Selvendran, S. Murdoch, D. G. Palmer, and N. Hogg. 1987. The human mononuclear phagocyte high-affinity Fc receptor, FcRI, defined by a monoclonal antibody, 10.1. Eur. J. Immunol. 17:1453-1459.

23. Peltz, G., K. Frederick, C. L. Anderson, and B. M. Peterlin. 1988. Characterization of the human monocyte high affinity Fc receptor (hu FcRI). Mol. Immunol. 25:243-250.

24. Graziano, R. F., and M. W. Fanger. 1987. Fc gamma RI and Fc gamma RII on monocytes and granulocytes are cytotoxic trigger molecules for tumor cells. J. Immunol. 139:3536-3541.

25. Schreiber, R. D. 1984. Identification of gamma-interferon as a murine macrophage-activating factor for tumor cytotoxicity. Contemp. Top. Immunobiol. 13:171-198.

26. Guyre, P. M., Morganelli, and R. Miller. 1983. Recombinant immune interferon increases immunoglobulin $\mathrm{G} \mathrm{Fc}$ receptors on cultured human mononuclear phagocytes. J. Clin. Invest. 72:393-397.

27. Akiyama, Y., M. D. Lubeck, Z. Steplewkski, and H. Koprowski. 1984. Induction of mouse IgG2a- and IgG3-dependent cellu- lar cytotoxicity in human monocytic cells (U937) by immune interferon. Cancer Res. 44:5127-5131.

28. Perussia, B., E. T. Dayton, R. Lazarus, V. Fanning, and G. Trinchieri. 1983. Immune interferon induces the receptor for monomeric IgG1 on human monocytic and myeloid cells. J. Exp. Med. 158:1092-1113.

29. Shen, L., P. M. Guyre, and M. W. Fanger. 1987. Polymorphonuclear leukocyte function triggered through the high affinity $\mathrm{Fc}$ receptor for monomeric IgG. J. Immunol. 139:534-538.

30. Petroni, K. C., L. Shen, and P. M. Guyre. 1988. Modulation of human polymorphonuclear leukocyte IgG Fc receptors and Fc receptor-mediated functions by IFN-gamma and glucocorticoids. J. Immunol. 140:3467-3472.

31. Girard, M. T., S. Hjaltadottir, A. N. Fejes-Toth, and P. M. Guyre. 1987. Glucocorticoids enhance the gamma-interferon augmentation of human monocyte immunoglobulin G Fc receptor expression. J. Immunol. 138:3235-3241.

32. Yancey, K. B., J. O’Shea, T. Chused, E. Brown, T. Takahashi, M. M. Frank, and T. J. Lawley. 1985. Human C5a modulates monocyte Fc and C3 receptor expression. J. Immunol. 135:465-470.

33. Ceuppens, J. L., F. J. Bloemmen, and J. P. Van Wauwe. 1985. T-cell unresponsiveness to the mitogenic activity of OKT3 antibody results from a deficiency of the monocyte Fc-gamma receptors for murine IgG2a and inability to cross-Ink the T3-Ti complex. J. Immunol. 135:165-171.

34. Tetteroo, P. A. T., C. E. van der Schoot, F. J. Visser, M. J. E. Bos, and A. E. G. Kr. von dem Borne. 1987. Three different types of $\mathrm{Fc}_{\gamma}$ receptors on human leukocytes defined by Workshop antibodies: $\mathrm{Fc}_{\gamma}$ Rlow of neutrophils, $\mathrm{Fc}_{\gamma}$ Rlow of K/NK lymphocytes, and $\mathrm{Fc}_{\gamma} \mathrm{RII}$. In Leukocyte Typing III, White Cell Differentiation Antigens. A. J. McMichael, editor. Oxford University Press, Oxford. 702-707.

35. Rosenfeld, S. I., R. J. Looney, J. P. Leddy, D. C. Phipps, G. N. Abraham, and C. L. Anderson. 1985. Human platelet Fc receptor for immunoglobulin G. Identification as a 40,000-molecular-weight membrane protein shared by monocytes. J. Clin. Invest. 76:23172322.

36. Jones, D. H., R. J. Looney, and C. L. Anderson. 1985. Two distinct classes of IgG Fc receptors on a human monocyte line (U937) defined by differences in binding of murine IgG subclasses at low ionic strength. J. Immunol. 135:3348-3353.

37. Stengelin, S., I. Stamenkovic, and B. Seed. 1988. The isolation of cDNAs for two distinct human Fc receptors by ligand affinity cloning. EMBO (Eur. Mol. Biol. Organ.) J. 7:1053-1059.

38. Looney, R. J., D. H. Ryan, K. Takahashi, H. B. Fleit, H. J. Cohen, G. N. Abraham, and C. L. Anderson. 1986. Identification of a second class of IgG Fc receptors on human neutrophils: A 40 kilodalton molecule also found on eosinophils. J. Exp. Med. 163:826-836.

39. Clarkson, S. B., and P. A. Ory. 1988. CD16: developmentally regulated $\mathrm{IgG} \mathrm{Fc}$ receptors on cultured human monocytes. J. Exp. Med. 167:408-420.

40. Willis, H. E., B. Browder, A. J. Feister, T. Mohanakumar, and S. Ruddy. 1988. Monoclonal antibody to human IgG Fc receptors: cross-linking of receptors induces lysosomal enzyme release and superoxide generation by neutrophils. J. Immunol. 140:234-239.

41. Huizinga, T. W., C. E. van der Schoot, C. Jost, R. Klaassen, M. Kleijer, A. E. von dem Borne, D. Roos, and P. A. Tetteroo. 1988. The PI-linked receptor FcRIII is released on stimulation of neutrophils. Nature (Lond.). 333:667-669.

42. Tosi, M. F., and M. Berger. 1988. Functional differences between the $40 \mathrm{kDa}$ and 50 to $70 \mathrm{kDa}$ IgG Fc receptors on human neutrophils revealed by elastase treatment and antireceptor antibodies. J. Immunol. 141:2097-2103.

43. Looney, R. J., G. N. Abraham, and C. L. Anderson. 1986. Human monocytes and U937 cells bear two distinct Fc receptors for IgG. J. Immunol. 136:1641-1647.

44. Peltz, G. A., M. L. Trounstine, and K. W. Moore. 1988. Cloned 
and expressed human Fc receptor for IgG mediates anti-CD3-dependent lymphoproliferation. J. Immunol. 141:1891-1896.

45. Anderson, C. L., D. H. Ryan, R. J. Looney, and P. C. Leary. 1987. Structural polymorphism of the human monocyte 40 kilodalton Fc receptor for IgG. J. Immunol. 138:2254-2256.

46. Tax, W. J., H. W. Willems, P. P. Reekers, P. J. Capel, and R. A. Koene. 1983. Polymorphism in mitogenic effect of IgGI monoclonal antibodies against T3 antigen on human $\mathrm{T}$ cells. Nature (Lond.). 304:445-447.

47. Tax, W. J., F. F. Hermes, R. W. Willems, P. J. Capel, and R. A. Koene. 1984. Fc receptors for mouse IgG1 on human monocytes: polymorphism and role in antibody-induced $\mathrm{T}$ cell proliferation. $J$. Immunol. 133:1185-1189.

48. Clement, L. T., A. B. Tilden, and N. E. Dunlap. 1985. Analysis of the monocyte $\mathrm{Fc}$ receptors and antibody-mediated cellular interactions required for the induction of $\mathrm{T}$ cell proliferation by anti-T3 antibodies. J. Immunol. 135:165-171.

49. Ceuppens, J. L., and F. van Vaeck. 1987. Direct demonstration of binding of anti-leu 4 antibody to the $40 \mathrm{kDa} \mathrm{Fc}$ receptor on monocytes as a prerequisite for anti-leu 4-induced $\mathrm{T}$ cell mitogenesis. $J$. Immunol. 139:4067-4071.

50. Rosenfeld, S. I., D. H. Ryan, R. J. Looney, C. L. Anderson, G. N. Abraham, and J. P. Leddy. 1987. Human Fc gamma receptors: stable inter-donor variation in quantitative expression on platelets correlates with functional responses. J. Immunol. 138:2869-2873.

51. Stewart, S. G., M. L. Trounstine, D. J. T. Vaux, T. Koch, C. L. Martens, I. Mellman, and K. W. Moore. 1987. Isolation and expression of cDNA clones encoding a human receptor for $\mathrm{IgG}\left(\mathrm{Fc}_{\gamma} \mathrm{RII}\right) . J$. Exp. Med. 166:1668-1684.

52. Hibbs, M. L., L. Bonadonna, B. M. Scott, I. F. McKenzie, and P. M. Hogarth. 1988. Molecular cloning of a human immunoglobulin G Fc receptor. Proc. Natl. Acad. Sci. USA. 85:2240-2244.

53. Fleit, H. B., S. D. Wright, and J. C. Unkeless. 1982. Human neutrophil Fc gamma receptor distribution and structure. Proc. Natl. Acad. Sci. USA. 79:3275-3279.

54. Perussia, B., and G. Trinchieri. 1984. Antibody 3G8, specific for the human neutrophil Fc receptor, reacts with natural killer cells. $J$. Immunol. 132:1410-1415.

55. Fleit, H. B., S. D. Wright, C. J. Durie, J. E. Valinsky, and J. C. Unkeless. 1984. Ontogeny of Fc receptors and complement receptor (CR3) during human myeloid differentiation. J. Clin. Invest. 73:516525 .

56. Simmons, D., and B. Seed. 1988. $\mathrm{Fc}_{\gamma}$ receptor of natural killer cells is a phospholipid-linked membrane protein. Nature (Lond.) 333:568-570.

57. Spiegelberg, H. L., H. Perlmann, and P. Perlmann. 1976. Interaction of $\mathrm{K}$ lymphocytes with myeloma proteins of different IgG subclasses. J. Immunol. 117:1464-1471.

58. Gergely, J., G. Sarmay, Z. Rozsnyay, D. R. Stanworth, and E. Klein. 1986. Binding characteristics and isotype specificity of Fc receptors on K cells. Mol. Immunol. 23:1203-1209.

59. Werner, G., A. E. G. Kr. von dem Borne, M. J. E. Bos, J. F. Tromp, C. M. van der Plas-van Dalen, F. J. Visser, C. P. Engelfriet, and P. A. T. Tetteroo. 1986. Localization of the human NA1 alloantigen on neutrophil Fc- $\gamma$ receptors. In Leukocyte Typing II V. 3 Human Myeloid and Hematopoietic Cells. E. L. Reinherz, B. F. Haynes, L. M. Nadler, and I. D. Bernstein, editors. Springer-Verlag, New York. 109-121.

60. Lanier, L. L., J. J. Ruitenberg, and J. H. Phillips. 1988. Functional and biochemical analysis of CD16 antigen on NK cells and granulocytes. J. Immunol. In press.

61. Selvaraj, P., W. F. Rosse, R. Silber, and T. A. Springer. 1988. The major Fc receptor in blood has a phosphatidylinositol anchor and is deficient in paroxysmal nocturnal haemoglobinuria. Nature (Lond.). 333:565-567.

62. Huizinga, T. W., C. E. van der Schoot, C. Jost, R. Klassen, M. Kleijer, A. E. von dem Borne, D. Roos, and P. A. Tetteroo. 1988. The
PI-linked receptor FcRIII is released on stimulation of neutrophils. Nature (Lond.). 333:565-567.

63. Trinchieri, G., T. O’Brien, M. Shade, and B. Perussia. 1984. Phorbol esters enhance spontaneous cytotoxicity of human lymphocytes, abrogate Fc receptor expression, and inhibit antibody-dependent lymphocyte-mediated cytotoxicity. J. Immunol. 133:1869-1877.

64. Anegon, I., M. C. Cuturi, G. Trinchieri, and B. Perussia. 1988. Interaction of Fc receptor (CD16) ligands induces transcription of interleukin 2 receptor (CD25) and lymphokine genes and expression of their products in human natural killer cells. J. Exp. Med. 167:452-472.

65. Egawa, S. E., T. Abo, and N. Hiwatashi. 1987. Enhancement of human natural killer activity by the monoclonal Leu- 11 antibodies. Cell. Immunol. 104:386-399.

66. van de Griend, R. J., W. J. Tax, B. A. van Krimpen, R. J. Vreugdenhil, C. P. Ronteltap, and R. L. Bolhuis. 1987. Lysis of tumor cells by $\mathrm{CD} 3+4-8-16+\mathrm{T}$ cell receptor alpha beta- clones, regulated via $\mathrm{CD} 3$ and $\mathrm{CD} 16$ activation sites, recombinant interleukin 2, and interferon beta 1. J. Immunol. 138:1627-1633.

67. Clarkson, S. B., R. P. Kimberly, J. E. Valinsky, M. D. Witmer, J. B. Bussel, R. L. Nachman, and J. C. Unkeless. 1986. Blockade of clearance of immune complexes by an anti-Fc gamma receptor monoclonal antibody. J. Exp. Med. 164:474-489.

68. Clarkson, S. B., J. B. Bussel, R. P. Kimberly, J. E. Valinsky, R. L. Nachman, and J. C. Unkeless. 1986. Treatment of refractory immune thrombocytopenic purpura with an anti-Fc gamma-receptor antibody. N. Engl. J. Med. 314:1236-1239.

69. Feister, A. J., B. Browder, H. E. Willis, T. Mohanakumar, and S. Ruddy. 1988. Pertussis toxin inhibits human neutrophil responses mediated by the 42-kilodalton IgG Fc receptor. J. Immunol. 141:228233.

70. Gresham, H. D., L. T. Clement, J. E. Volanakis, and E. J. Brown. 1987. Cholera toxin and pertussis toxin regulate the Fc receptor-mediated phagocytic response of human neutrophils in a manner analogous to regulation by monoclonal antibody 1C2. J. Immunol. 139:4159-4166.

71. Blackburn, W. D., Jr., L. W. Heck, W. J. Koopman, and H. D. Gresham. 1987. A low molecular weight, heat-labile factor enhances neutrophil Fc receptor-mediated lysosomal enzyme release and phagocytosis. Arthritis Rheum. 30:1006-1014.

72. Brozna, J. P., N. F. Hauff, W. A. Phillips, and R. B. Johnston. 1988. Activation of the respiratory burst in macrophages: phosphorylation specifically associated with $\mathrm{Fc}$ receptor-mediated stimulation. $J$. Immunol. 141:1642-1647.

73. Young, J. D.-E., S. S. Ko, and Z. A. Cohn. 1984. The increase in intracellular free calcium associated with $\operatorname{IgG}_{\gamma} 2 \mathrm{~b} / \gamma 1 \mathrm{Fc}$ receptor-ligand interaction: role in phagocytosis. Proc. Natl. Acad. Sci. USA. 81:5430-5434.

74. Lew, D. P., T. Andersson, J. Hed, F. Di Virgilio, T. Pozzan, and O. Stendahl. 1985. $\mathrm{Ca}^{2+}$ dependent and $\mathrm{Ca}^{2+}$-independent phagocytosis in human neutrophils. Nature (Lond.). 315:509-511.

75. Di Virgilio, F., B. C. Meyer, S. Greenberg, and S. C. Silverstein. 1988. Fc receptor-mediated phagocytosis occurs in macrophages at exceedingly low cytosolic Ca2+ levels. J. Cell Biol. 106:657-666.

76. Phillips, N. E., and D. C. Parker. 1985. Subclass specificity of Fc gamma receptor-mediated inhibition of mouse B cell activation. $J$. Immunol. 134:2835-2838.

77. Phillips, N. E., and D. C. Parker. 1984. Cross-linking of B (lymphocyte) Fc gamma receptors and membrane immunoglobulin inhibits anti-immunoglobulin-induced blastogenesis. J. Immunol. 132:627-632.

78. Wilson, H. A., D. Greenblatt, C. W. Taylor, J. W. Putney, R. Y. Tsien, F. D. Finkelman, and T. M. Chused. 1987. The B lymphocyte calcium response to anti-Ig is diminished by membrane immunoglobulin cross-linkage to the Fc gamma receptor. J. Immunol. 138:17121718.

79. Goroff, D. K., and F. D. Finkelman. 1988. Activation of B cells in vivo by a $\mathrm{Fab} / \mathrm{Fc}$ fragment of a monoclonal anti-IgD antibody 
requires an interaction between the antibody fragment and a cellular IgG Fc receptor. J. Immunol. 140:2919-2924.

80. Anasetti, C., P. J. Martin, C. H. June, K. E. Hellstrom, J. A. Ledbetter, P. S. Rabinovitch, Y. Morishita, I. Hellstrom, and J. A. Hansen. 1987. Induction of calcium flux and enhancement of cytolytic activity in natural killer cells by cross-linking of the sheep erythrocyte binding protein $(\mathrm{CD} 2)$ and the Fc-receptor (CD16). J. Immunol. 139:1772-1779.

81. Gidlund, M., P. Rossi, P. Cotran, U. Ramstedt, and H. Wigzell. 1988. In human monocytes a strong correlation exists between expression of the M3 antigen, Fc-mediated phagocytic activity and failure to participate in extracellular antibody-dependent cytotoxicity. Eur. J. Immunol. 18:477-480.

82. Shen, L., P. M. Guyre, C. L. Anderson, and M. W. Fanger. 1986. Heteroantibody-mediated cytotoxicity: antibody to the high affinity $\mathrm{Fc}$ receptor for IgG mediates cytotoxicity by human monocytes that is enhanced by interferon-gamma and is not blocked by human IgG. J. Immunol. 137:3378-3382.

83. Titus, J. A., P. Perez, A. Kaubisch, M. A. Garrido, and D. M. Segal. 1987. Human K/natural killer cells targeted with hetero-crosslinked antibodies specifically lyse tumor cells in vitro and prevent tumor growth in vivo. J. Immunol. 139:3153-3158. 